\title{
FAKTOR-FAKTOR YANG BERPENGARUH TERHADAP KEBERDAYAAN ANGGOTA GABUNGAN KELOMPOK TANI PADA SEKOLAH LAPANG
}

\author{
Lesi Oktiwanti \\ e-mail: lesi.oktiwanti@gmail.com \\ Universitas Siliwangi Tasikmalaya \\ JI. Siliwangi 24 Tasikmalaya, Jawa Barat
}

\begin{abstract}
Abstrak: Tujuan dari penelitian ini adalah untuk menggambarkan dan menganalisis pengaruh sumber daya, pengetahuan dan keterampilan, peluang terhadap keberdayaan anggota Gapoktan; serta menggambarkan dan menganalisis faktor yang paling berpengaruh terhadap keberdayaan anggota Gapoktan. Penelitian ini dilakukan di Gapoktan Subur Mukti, Desa Cikalong Kecamatan Cimaung Kabupaten Bandung pada tahun 2010 dengan menggunakan metode deskriptif kuantitatif. Data dikumpulkan dengan menyebarkan kuesioner kepada 78 orang sampel dan dianalisis dengan analisis jalur. Hasil penelitian menyatakan bahwa sumber daya, pengetahuan dan keterampilan, dan peluang memiliki pengaruh yang positif dan signifikan terhadap keberdayaan. Hasil analisis menyebutkan bahwa sumber daya memiliki pengaruh sebesar 0,158 , pengetahuan dan keterampilan memiliki pengaruh paling besar 0,434 , dan variabel peluang memiliki pengaruh sebesar 0,14 . Sehingga secara keseluruhan faktor-faktor independen tersebut memiliki pengaruh sebesar 0,732 terhadap variabel dependen. Rekomendasi untuk penelitian selanjutnya meneliti mengenai pengaruh 'kekuatan dalam' (power within) terhadap keberdayaan.
\end{abstract}

Kata-kata Kunci: keberdayaan, keterampilan, kelompok tani, sumber daya, peluang, pengetahuan.

\section{INFLUENCING FACTORS ON THE POWER OF FARMER GROUP MEMBERS IN LAPANG SCHOOL}

\begin{abstract}
The purpose of this research is to describe and analyze the effects of resource, knowledge and skill opportunity for the power of Gapoktan members as well as to describe and analyze the factors mostly influencing the power of Gapokan members. The research was conducted in Gapoktan Subur Murni, Cikalong Village, Cimaung Sub-district, Bandung District, in 2010 applying quantitative descriptive method. The data were collected by distributing questionnairer to 78 samples and analyzed using path analysis. The research result indicate resource, knowledge and skill, and opportunity possess positive and significant effects to power. The analysis result stated resource has effect of 0.258 , knowledge and skill of 0.434 (the highest), and opportunity of 0.14. Over all the independent variables possess the effect of 0.732 to dependent variable. For further research, it is recommended to search the effect of 'power within' to empowerment.
\end{abstract}

Keywords: power, skill, farmer group, resource, opportunity, knowledge.

\section{PENDAHULUAN}

Indonesia merupakan salah satu negara agraris, karenanya pertanian menjadi salah satu masalah pokok yang harus mendapatkan perhatian utama kebijakan pemerintah. Permasalahan pertanian di Indonesia salah satunya disebabkan oleh kecenderungan manusia yang menggunakan prinsip ekonomi koboy dalam arti menggunakan sumber daya secara berlebihan seakan menutup mata dengan kenyataan bahwa sumber daya alam kita terbatas dan bisa rusak.

Seperti halnya dengan eksploitasi tanah subur secara besar-besaran yang baik untuk pertanian, malah digunakan untuk pemukiman, pabrik-pabrik, gedung dan sejenisnya. Pada akhirnya lahan pertanian beralih pada lereng gunung dan menebang habis pegunungan yang pada umumnya tidak memiliki unsur hara tanah yang baik untuk pertanian. Bukan hanya masalah sumber daya, petani di Indonesia pada umumnya memiliki tingkat pendidikan yang rendah dan tidak mengetahui pengelolaan pertanian yang benar. Kamil (2009) menjelaskan bahwa "masyarakat pada umumnya bukanlah students by profession, tetapi mayoritas buruh, petani, pengrajin, tukang, 
nelayan, pengusaha kecil, ibu rumah tangga dan pegawai lain yang kurang bahkan tidak memiliki akses terhadap informasi”. Oleh karena itu, pendidikan dan pemberdayaan memiliki peran yang sangat penting dalam memenuhi kebutuhan belajar masyarakat khususnya petani.

Pada hakikatnya, pemberdayaan merupakan salah satu cara untuk memperbaiki kedudukan individu dalam masyarakat. Suharto (2006) menyebutkan bahwa secara konseptual, pemberdayaan atau pemberkuasaan (empowerment) berasal dari kata "power" (kekuasaan atau keberdayaan). Kekuasaan yang sering dikaitkan dengan kemampuan kita untuk membuat orang lain melakukan apa yang kita inginkan, terlepas dari keinginan dan minat mereka. Namun kekuasaan di sini tidak diartikan sebagai kekuasaan semata, tetapi juga kekuatan, kemampuan, atau potensi yang ada dalam diri orang yang diberdayakan.

Pemberdayaan masyarakat juga dapat diartikan menyiapkan kepada masyarakat dengan sumber daya, kesempatan, pengetahuan dan keahlian untuk meningkatkan kapasitas diri masyarakat di dalam menentukan masa depan mereka, serta berpartisipasi dan mempengaruhi Pendapat tersebut dipertegas lagi oleh Pearson dalam Heryanto yang menyatakan bahwa konsep pemberdayaan menekankan bahwa orang memperoleh keterampilan, pengetahuan, dan kekuasaan yang cukup untuk mempengaruhi kehidupannya dan kehidupan orang lain yang menjadi perhatiannya. Selain itu Solomon dalam Hikmat menambahkan faktor-faktor yang menyebabkan masyarakat tidak berdaya bahwa ketidakberdayaan dalam individu dan kelompok sosial dianggap sebagai ketidakmampuan untuk mengatur emosi, skill (keahlian dan keterampilan), pengetahuan (knowledge) dan sumber-sumber material lainnya dalam tatanan nilai-nilai sosial. (Hikmat, 2004)

Dilihat dari karakteristik masyarakat di atas, pendidikan nonformal dipandang lebih tepat digunakan untuk memenuhi kebutuhan belajar masyarakat karena pendekatan pendidikan nonformal didasarkan pada kebutuhan masyarakat dengan cara menggali dan menggunakan apa yang ada di masyarakat untuk menumbuhkembangkan pengetahuan, sikap, keterampilan kearah kemandirian (Kindervatter, 1979). Oleh karena itu, berbicara pendidikan nonformal sangat erat kaitannya dengan proses pemberdayaan masyarakat.

Pendidikan nonformal yang berasaskan pendidikan sepanjang hayat berorientasi pada terjadinya proses perubahan sikap dan perilaku warga belajar ke arah mendewasa (maturing person). Menurut Sudjana (2004), orang mendewasa adalah orang yang senantiasa mengembangkan potensi diri dan berupaya mencapai kepuasan diri dalam kehidupan yang baik dan bermakna bagi dirinya dan lingkungannya.

Salah satu pendekatan pemberdayaan melalui pendidikan nonformal adalah melalui pendekatan kelompok. Coombs dalam Kamil (2009) menjelaskan bahwa pendekatan kelompok dalam penyelenggaraan pendidikan nonformal akan lebih efektif dalam proses pembelajaran atau transfer pengetahuan dan keterampilan. Wilson dalam Smith (2004) memandang penggunaan kerja kelompok membawa perubahan nilai-nilai individu dan masyarakat secara keseluruhan. Dia berpendapat bahwa kerja kelompok adalah proses melalui mana kehidupan kelompok dipengaruhi oleh seorang pekerja yang diarahkan proses menuju tercapainya tujuan sosial yang dikandung dalam filsafat demokratis.

Salah satu bentuk pemberdayaan masyarakat melalui pendidikan nonformal dengan pendekatan kelompok atau social group work untuk mengatasi permasalahan di atas adalah program pemerintah dalam pembangunan pertanian dan pedesaan melalui Gabungan Kelompok Tani (Gapoktan). Pembentukan dan pengembangan Gapoktan dibentuk di setiap desa dengan menggunakan prinsip kemandirian lokal yang dicapai melalui prinsip keotonomian dan pemberdayaan.

Di awal 1990-an Gapoktan sesungguhnya telah dikenal. Saat ini, Gapoktan diberi pemaknaan baru, termasuk bentuk dan peran yang baru. Gapoktan menjadi lembaga penghubung petani satu desa dengan lembaga-lembaga lain di luarnya. Gapoktan diharapkan berperan untuk fungsi-fungsi pemenuhan permodalan pertanian, pemenuhan sarana produksi, pemasaran produk pertanian, dan termasuk untuk menyediakan berbagai informasi yang dibutuhkan petani.

Tujuan utama pembentukan dan penguatan Gapoktan adalah untuk memperkuat kelembagaan petani yang ada, sehingga pembinaan pemerintah kepada petani akan terfokus dengan sasaran yang 
jelas (Departemen Pertanian dalam Syahyuti, 2007). Kelembagaan pertanian tersebut meliputi "kelembagaan penyuluhan, kelompok tani, Gapoktan, koperasi tani, penangkar benih, pengusaha benih, institusi perbenihan lainnya, kios, KUD, pasar desa, pedagang, asosiasi petani, asosiasi industri olahan, asosiasi benih, dan lainlain.

Salah satu Gapoktan yang telah berkembang adalah Gapoktan Subur Mukti yang terletak di Desa Cikalong Kecamatan Cimaung Kabupaten Bandung. Gapoktan yang berdiri pada tanggal 8 Februari 2008 ini awalnya merupakan kelompok tani yang melakukan diskusi mengenai permasalahanpermasalahan pertaniannya. Pada tahun 2009 hingga sekarang mereka diberikan pelatihan yang merupakan program pemerintah untuk meningkatkan pemahaman para petani dalam pengelolaan pertanian yang dikenal dengan sekolah lapangan. Gapoktan Subur Mukti yang mulanya sebagai kelompok tani (poktan), sekarang memiliki lima poktan binaan, yaitu Poktan Subur Mukti yang berada di Kampung Babakan Saputra, Kewirausahaan Wanita Tani (KWT) Subur Mukti di Palasari, KWT Mekar Mulya, Poktan Harapan Mulya di Palasari, dan Poktan Sedap Malam di Cikalong.

Dengan potensi lingkungan daerah yang berbeda namun komoditas yang berbeda Poktan tersebut bergabung untuk meningkatkan pengetahuan dan keterampilannya dalam kemampuan teknis pertanian, sharing pengalaman untuk memecahkan permasalahan-permasalahan yang ada di lapangan baik melalui agen penyuluh pendamping pertanian maupun antarpoktan. Selain itu, kelompok tani tersebut juga mengembangkan penguatan-penguatan baik dari segi permodalan, penyediaan pupuk, penyediaan pakan dan pengembangan kemitraan untuk meningkatkan posisi tawar petani. Bahkan, untuk menguatkan perekonomian Gapoktan tersebut, mereka mengintegrasikan pengelolaan pertanian dengan peternakan yang mereka miliki, misalnya dengan pembuatan pupuk kandang, pakan ternak dan bokasi. Dari segi hasil pertaniannya, melalui KWT yang dimiliki mereka juga mengembangkan produksi olahan makanan khas dan unik salah satunya sorgun dan dendeng daun ketela pohon. Gapoktan Subur Mukti merupakan salah satu Gapoktan Mandiri dan terbaik di Kabupaten Bandung.

Sejatinya, dalam suatu social group work sebagai wahana pemberdayaan dan pembelajaran, masyarakat khususnya para petani yang mengikuti Gapoktan tersebut juga akan berdaya dan mandiri. Berdaya dengan pengetahuan dan keterampilan yang didapat untuk memanfaatkan sumber daya dilingkungannya dan memanfatkan informasi peluang-peluang usaha, karena memberdayakan suatu kelompok berarti juga memberdayakan individu. Oleh karena untuk membuktikan pengaruh dari sumber daya yang dimiliki anggota petani, pengetahuan dan keterampilan, dan peluang terhadap keberdayaan anggota kelompok Gapoktan, maka peneliti tertarik untuk mengangkat penelitian yang berjudul "Faktor-Faktor yang Berpengaruh terhadap Keberdayaan Anggota Gabungan Kelompok Tani”.

Berdasarkan pada latar belakang di atas, maka yang menjadi rumusan masalah dari penelitian ini adalah: Apakah keberdayaan anggota gabungan kelompok tani (GAPOKTAN) Subur Mukti di Desa Cikalong Kecamatan Cimaung Kabupaten Bandung dipengaruhi oleh sumber daya, pengetahuan dan keterampilan, serta peluang?

\section{METODE PENELITIAN}

Penelitian ini menggunakan metode deskriptif dengan pendekatan kuantitatif. Penelitian ini dilaksanakan pada program Sekolah Lapang Gapoktan Subur Mukti yang terletak di Desa Cikalong Kecamatan Cimaung Kabupaten Bandung pada bulan April sampai dengan September 2010.

Populasi penelitian ini sebanyak 100 orang dan sampel sebanyak 78 orang yang diambil melalui simple random sampling dengan tingkat kepercayaan $95 \%$. Alat pengumpul data penelitian ini adalah menggunakan angket. Teknik analisis data hasil penelitian ini menggunakan analisis jalur untuk mengetahui besar koefisien jalur pengaruh variabel sumber daya (X1), pengetahuan dan keterampilan $(X 2)$ dan peluang (X3) terhadap keberdayaan (Y), selanjutnya dilakukan pengujian hipotesis untuk mengetahui pengujian kebermaknaan setiap kooefisien jalur yang telah dihitung (theory trimming), serta menguji perbedaan besarnya koefisien jalur dalam sebuah substruktur. 


\section{HASIL DAN PEMBAHASAN}

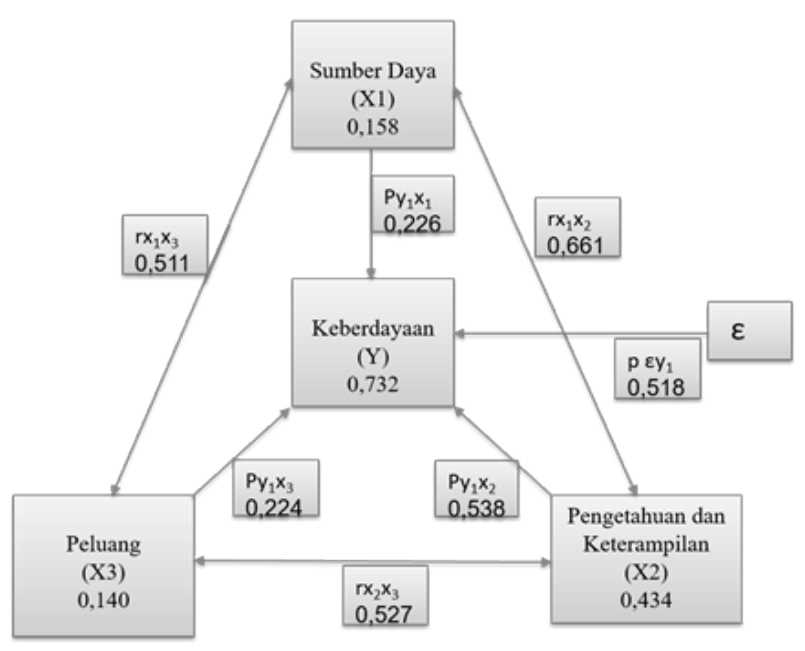

Gambar 1. Diagram jalur faktor-faktor yang berpengaruh terhadap keberdayaan

Seperti yang telah digambarkan dalam hasil penelitian di atas, dapat diketahui teori yang menyebutkan bahwa sumber daya, pengetahuan dan keterampilan, serta peluang memiliki pengaruh terhadap keberdayaan anggota masyarakat. Secara keseluruhan berdasarkan hasil analisis jalur independen (variabel sumber daya, variabel pengetahuan dan keterampilan dan variabel peluang) tersebut memiliki pengaruh yang kuat dengan koefisien determinasi sebesar 0,732 atau $73,2 \%$ terhadap variabel dependen (variabel keberdayaan), serta 0,268 atau $26,8 \%$ dari variabel lain yang tidak diteliti. Variabel pengetahuan dan keterampilan memiliki pengaruh total paling besar yakni sebesar 0,434 diikuti oleh variabel sumber daya dan terakhir variabel peluang. Sedangkan pengaruh tidak langsung dari variabel sumber daya, pengetahuan dan keterampilan serta peluang terhadap keberdayaan, pengaruh terbesar ditempati oleh variabel sumber daya melalui pengetahuan dan keterampilan, dimensi pengetahuan dan keterampilan melalui peluang dan pengaruh terkecil adalah sumber daya melalui peluang.

Dari hasil penelitian, pengaruh variabel lain yang tidak diteliti adalah power within atau psychological power yang memang berpengaruh terhadap keberdayaan, seperti yang diungkapkan oleh Solomon dalam Harry Hikmat (2004) menambahkan faktor-faktor yang menyebabkan masyarakat tidak berdaya bahwa ketidakberdayaan dalam individu dan kelompok sosial dianggap sebagai ketidakmampuan untuk mengatur emosi, skill (keahlian dan keterampilan), pengetahuan (knowledge), dan sumber-sumber material lainnya dalam tatanan nilai-nilai sosial.

Pemberdayaan jika dilihat dari sebuah proses, dibagi ke dalam empat tingkat kekuasaan: (a) power over (kekuasaan atas), (b) power to (kekuasaan untuk), (c) power with (kekuasaan dengan), dan (d) power within (kekuatan dalam). Gagasan kekuasaan mengacu pada kesadaran diri, harga diri, identitas dan ketegasan (know how tobe) (Commision on Woman and Development, 2007). Hal ini mengacu pada bagaimana individu, melalui analisis-diri dan kekuatan internal, dapat mempengaruhi kehidupan mereka dan membuat perubahan. Selain itu, menurut Jhon Friedman yang mengatakan bahwa kekuatan dalam masyarakat terbagi ke dalam tiga bidang, yaitu sosial, politik dan psikologi.

Masing masing variabel sumber daya memiliki pengaruh sebesar 0,158 , pengetahuan dan keterampilan memiliki pengaruh sebesar 0,434, peluang memiliki pengaruh sebesar 0,14. Penelitian ini memiliki koefisien residu sebesar 0,518 yang menunjukan ada variabel lain yang mempengaruhi variabel $Y$ (keberdayaan) dan belum teridentifikasi oleh teori, koefisien residu juga menunjukkan kekeliruan pengukuran. Jika dilihat secara terpisah pengaruh antar variabel dalam arti $X_{1}$ atau sumber daya terhadap $Y$ atau keberdayaan, $X_{2}$ pengetahuan dan keterampilan terhadap $Y$ atau keberdayaan dan $\mathrm{X}_{3}$ peluang terhadap keberdayaan menunjukan pengaruh yang rendah, pengetahuan dan keterampilan yang memiliki skor paling tinggi pun tidak mencapai $50 \%$ dari keseluruhan, yakni hanya mencapai $43,4 \%$, apalagi pengaruh sumber daya dan peluang. Namun, jika faktor-faktor tersebut digabungkan, maka akan menghasilkan pengaruh yang besar terhadap keberdayaan. Artinya, petani atau anggota Gapoktan Subur Mukti belum dikatakan berdaya jika hanya memiliki salah satu faktor.

Sebagai contoh, jika petani memiliki sumber daya yang memadai namun ia tidak memiliki pengetahuan dan keterampilan atau akses terhadap informasi, dan tidak memiliki peluang untuk usaha pertaniannya maka ia akan memiliki keberdayaan yang rendah karena pengaruh sumber daya hanya $15,8 \%$. Jika petani hanya memiliki peluang usaha, namun tidak memiliki sumber daya yang memadai dan tidak memiliki pengetahuan dan keterampilan maka ia tidak dapat memanfaatkan peluang usaha 
dengan baik apalagi tidak memiliki sumber daya misalnya kepemilikan tanah merupakan aspek penting dalam pertanian, maka ia belum dapat berdaya.

Sama halnya dengan pengetahuan dan keterampilan, jika petani hanya memiliki pengetahuan dan keterampilan namun tidak memiliki akses terhadap peluang dan tidak memiliki sumber daya yang mendukung dan memadai maka ia tidak dapat memanfaatkan pengetahuan dan keterampilan tersebut dengan efektif.

Gambar 2 berikut adalah grafik persentase pengaruh tiap variabel $\mathrm{X}_{1}, \mathrm{X}_{2}$ dan $\mathrm{X}_{3}$ atau sumber daya, pengetahuan dan keterampilan, serta peluang terhadap keberdayaan.

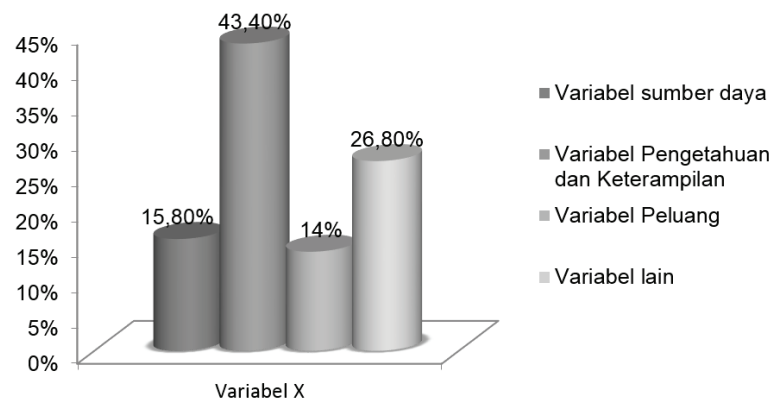

Gambar 2. Persentase determinasi masingmasing variabel independen penelitian

Masing-masing variabel juga memiliki keterkaitan atau hubungan satu sama lain: Variabel sumber daya dan variabel pengetahuan memiliki hubungan/ koefisien korelasi yang kuat yaitu sebesar 0,661 , hal ini menunjukkan bahwa jika anggota Gapoktan Subur Mukti menggunakan berbagai media baik media cetak maupun media elektronik, mendapatkan informasi atau pengetahuan dan keterampilan dari berbagai media, penyuluh pertanian, pendamping, dan teman sebaya, inovatif, dan senang berdiskusi maka dengan pengetahuan dan keterampilan tersebut ia akan dapat memanfaatkan sumber daya yang dimiliki untuk mencapai keberdayaan.

Variabel sumber daya dan variabel peluang memiliki hubungan yang sedang dengan koefisien korelasi sebesar 0,511, sedangkan variabel pengetahuan dan peluang memiliki hubungan/ korelasi yang sedang pula yakni sebesar 0,527.

Variabel sumber daya yang meliputi ketersediaan dukungan keluarga dan sosial, infrastruktur sosial ekonomi, alam, dan infrastruktur fisik anggota Gapoktan memiliki rata-rata sebesar 36,256. 15 dari skor keseluruhan 45 atau 19,23 $\%$ memiliki sumber daya yang rendah, 48 orang atau sekitar $61,54 \%$ memiliki sumber daya yang sedang, dan 15 orang atau 19,23\% anggota Gapoktan memiliki sumber daya yang tinggi. Dikatakan memiliki sumber daya yang tinggi, sedang atau rendah, itu dilihat dari besar atau kecilnya dukungan dari keluarga, teman atau kelompok, dan pemerintah; memadai atau tidaknya sumber daya alam baik hayati maupun nonhayati, dan ketersediaan dukungan dari pelayanan sosial.

Faktor kedua yang berpengaruh terhadap keberdayaan gabungan kelompok tani adalah sumber daya. Kelompok masyarakat dengan pemilikan faktor produksi atau sumber daya produktivitas rendah, menghasilkan tingkat kesejahteraan rendah (Kartasasmita,1996). Salah satu sumber daya utama seorang petani adalah kepemilikan tanah. Secara keseluruhan lebih dari $60 \%$ anggota Gapoktan memiliki tanah milik pribadi. Dari hasil observasi, sumber daya alam di Gapoktan Subur Mukti dapat dikatakan memadai karena masih merupakan daerah yang subur dengan air yang berlimpah. Lingkungan sekitar Gapoktan memiliki infrasruktur sosial ekonomi dan fisik yang sangat memadai sehingga sumber daya juga memiliki pengaruh terhadap produktivitas pertanian. Dengan pengetahuan dan keterampilan yang telah dimiliki anggota Gapoktan memanfaatkan sumber daya alam yang dimiliki bahkan kotoran/ sampah hasil produksi akan bermanfaat jika dikelola dengan baik. Setiap poktan dengan komoditas padi masing-masing memiliki 1 kerbau untuk membajak sawahnya. Kotoran kerbau tersebut mereka olah menjadi pupuk organik yang berguna untuk pertanian mereka tanpa menggunakan pupuk kimia. Hasil perkebunan pun sebagian tidak dijual secara langsung tapi mereka olah menjadi panganan yang unik dan bernilai ekonomi yang tinggi.

Variabel pengetahuan dan keterampilan yang meliputi tingkat pendidikan, pemanfaatan media cetak dan media elektronik, berdiskusi dengan penyuluh, dan saling membantu dalam memecahkan masalah usaha dengan teman sebaya atau kelompok anggota Gapoktan memiliki rata-rata 27,32 dari skor keseluruhan 36. Anggota Gapoktan yang memiliki pengetahuan dan keterampilan yang rendah sekitar 13 orang atau 16,67\%, dan anggota yang memiliki pengetahuan dan keterampilan yang sedang sekitar 52 orang atau 66,67\%, dan anggota 
yang memiliki pengetahuan dan keterampilan yang tinggi adalah 13 orang atau 16,67\%.

Seperti yang telah dipaparkan sebelumnya bahwa faktor yang paling berpengaruh pada keberdayaan anggota Gapoktan Subur Mukti adalah pengetahuan dan keterampilan yang dimiliki oleh anggota. Seperti yang dikemukakan oleh Trecker (1948) social group work adalah suatu proses dan metode melalui individu dalam kelompok dalam pengaturan lembaga sosial dibantu oleh seorang pekerja untuk menghubungkan dirinya dengan orang lain dan memberikan pengalaman pertumbuhan kesempatan sesuai dengan kebutuhan dan kapasitas. Dalam kerja kelompok sosial, kelompok itu sendiri yang digunakan oleh individu dengan bantuan pekerja, sebagai alat utama perubahan kepribadian, pertumbuhan dan perkembangan.

Sebagai social group work, Gapoktan Subur Mukti memfasilitasi anggota di setiap poktan untuk berbagi pengetahuan, pengalaman sekitar pertanian dan peluang-peluang, serta keterampilan teknis. Bersama penyuluh dan fasilitator dari gapoktan anggota diberikan pengetahuan dan keterampilan baik secara teori maupun praktik mengenai pengelolaan pertanian dari mulai memilih bibit unggul, meneliti anakan, pengairan, pengolahan tanah, pengendalian hama, pemberian pupuk organik sampai pada penanganan pascapanen dan pengolahan hasil panen.

Menghimpun minat dan keahlian yang tersedia di masyarakat lalu membuatnya dapat dimanfaatkan dan diakses secara luas, dapat menjadi aktivitas pembangunan berharga; tindakan untuk menghimpun sumber daya yang ada dapat merangsang minat dan keterlibatan masyarakat (Jim Ife, 2008).

Dari hasil wawancara kepada delapan orang anggota Gapoktan petani padi dewasa, produktivitas padi mereka meningkat sebanyak $22 \%$. Petani yang sebelumnya tidak memiliki takaran atau aturan yang benar mengenai pengelolaan pertanian dan perkebunan, dengan pengelolaan yang efektif dan efisien akan menghasilkan produktivitas pertanian yang efektif dan efisien pula. Tidak hanya fasilitator dan penyuluh yang memberikan pengetahuan dan keterampilan, anggota petani juga ikut mengemukakan pengalaman hasil praktiknya.

Walaupun dari hasil observasi petani wanita (anggota) kurang berperan dalam pembelajaran dalam arti mengemukakan pengalaman, ide, dan masukan tapi semua anggota sangat antusias mendengarkan dengan seksama pembelajaran yang diberikan. Selain anggota diberi pemahaman mengenai pengelolaan pertanian, bersama penyuluh mereka juga belajar mengenai pengorganisasian poktan dan administrasi yang tertib. Tidak ada diskriminasi gender dalam Gapoktan Subur Mukti ini, semua anggota memiliki kesempatan untuk mengikuti pembelajaran, ikut dalam kepengurusan atau penngelolaan.

Variabel peluang yang meliputi peluang dari pemerintah pusat, peluang dari informasi penyuluh dalam kegiatan Gapoktan, dan peluang dari saudara serta rekan anggota Gapoktan Subur Mukti memiliki rata-rata 18,76 dari skor keseluruhan 24. Anggota Gapoktan tidak memiliki peluang yang rendah, karena sebanyak 41 orang atau 52,56\% memiliki peluang yang sedang dan 37 orang atau $47,44 \%$ memiliki peluang yang tinggi.

Variabel ketiga yang memiliki pengaruh terhadap keberdayaan anggota Gapoktan Subur Mukti adalah peluang. Intervensi pengembangan manusia (human development) adalah dalam upaya meningkatkan kemampuan manusia agar memiliki jangkauan pilihannya secara lebih luas. Jangkauan pilihan tersebut bermacam-macam dan berubah sesuai dengan keadaan dan waktu. Terdapat tiga pilihan yang bersifat pokok, yakni (a) memiliki kemampuan untuk menempuh hidup dengan harapan hidup yang panjang dan sehat, (b) memiliki kesempatan dan kemampuan untuk memperoleh pendidikan agar dapat menanggapi kemajuan zaman, serta (c) memperoleh kesempatan akses dalam mengusahakan sumber-sumber untuk menaikan tingkat kehidupan (Hikmat, 2004)

Dari hasil wawancara terhadap pengurus dan Penyuluh, anggota Gapoktan diberikan informasiinformasi peluang usaha. Seperti informasi harga, pasar, promosi, kemitraan, sumber pendanaan, dan usaha baru. Dari sekian banyak informasi tersebut, yang kurang termanfaatkan adalah informasi pasar baik pasar input maupun pasar output. Dalam arti hanya hasil perkebunan dan olahan makanan saja yang memanfaatkan informasi pasar output, sedangkan hasil pertanian padi kurang dapat dipasarkan karena tanah yang produksinya pun terbatas, sehingga masih menjadi konsumsi rumah tangga/ keluarga belum menjadi agribisnis.

Sedangkan untuk variabel keberdayaan dengan sub variabel kekuasaan dalam keluarga, 
dan luasnya partisipasi dan kemampuan mengakses pelayanan sosial anggota Gapoktan Subur Mukti memiliki rata-rata 40,03 dari skor keseluruhan sebesar 51. Maksudnya, jika anggota Gapoktan Subur Mukti memiliki kemampuan dalam mempengaruhi dan berkontribusi dalam keluarga, sderta dapat berpartisipasi aktif dalam kegiatan di dalam kelompok dan lingkungannya maka keberdayaan dari anggota Gapoktan Subur Mukti dikatakan tinggi dan sebaliknya jika semua aspek tersebut rendah maka keberdayaannyapun akan rendah. Anggota Gapoktan yang memiliki keberdayaan yang rendah sekitar 12 orang atau $15,38 \%$, anggota yang memiliki keberdayaan yang sedang sekitar 49 orang atau $62,82 \%$, dan anggota yang memiliki keberdayaan yang tinggi adalah 17 orang atau $21,8 \%$.

Indikator keberdayaan menurut Jim Ife adalah peningkatan kapasitas dalam kehidupannya dan partisipasi dalam masyarakatnya. Anggota Gapoktan memiliki kapasitas dalam pengambilan keputusan keluarga, ikut serta dalam pengelolaan ekonomi keluarga tidak hanya kepala keluarga tetapi pasangannya. Dan berpartisipasi dalam lingkungan masyarakat dengan cara ikut serta dalam pengambilan keputusan, ikut serta mengelola dan mengambil bagian dalam kepengurusan program sebagai bentuk kepercayaan diri dan tanggung jawab. Dilihat dari segi partisipasi anggota dalam Gapoktan, tidak ada diskriminasi gender, dalam arti semua anggota baik laki-laki maupun perempuan memiliki hak yang sama sebagai anggota. Bahkan banyak yang anggota perempuan yang mengikuti kepengurusan kegiatan dan ikut andil dalam pengambilan keputusan serta ikut serta dalam mengawasi, mengelola sampai pada mengevaluasi kegiatan yang ada di Gapoktan Subur Mukti.

\section{PENUTUP}

\section{Kesimpulan}

Hasil penelitian dengan populasi sebesar 100 orang dan sampel sebesar 78 orang dan tingkat kepercayaan $95 \%$ menyatakan bahwa sumber daya, pengetahuan dan keterampilan, dan peluang memiliki pengaruh yang positif dan signifikan terhadap keberdayaan.

Dari hasil analisis menggunakan analisis jalur membuktikan bahwa sumber daya memiliki pengaruh sebesar 0,158 , pengetahuan dan keterampilan memiliki pengaruh sebesar 0,434, dan variabel pengetahuan memiliki pengaruh sebesar 0,14 . Sehingga secara keseluruhan faktorfaktor independen tersebut memiliki pengaruh sebesar 0,732 terhadap variabel dependen. Dari hasil pengujian analisis jalur tersebut dapat diketahui bahwa secara terpisah antara variabel independen sumber daya, pengetahuan dan keterampilan serta peluang akan memiliki pengaruh yang rendah terhadap keberdayaan, namun jika digabungkan secara keseluruhan maka variabel independen tersebut memiliki pengaruh yang besar terhadap keberdayaan. Variabel pengetahuan dan keterampilan memiliki pengaruh sebesar 0,434 terhadap keberdayaan anggota Gapoktan Subur Mukti.

Dalam penelitian ini terdapat variabel residu yang menunjukkan bahwa terdapat variabel lain yang berpengaruh terhadap keberdayaan, belum teridentifikasi oleh teori, koefisien residu juga menunjukkan kekeliruan pengukuran. Dari hasil penelitian dan hasil pengolahan dari berbagai sumber, variabel residu tersebut menyangkut faktor usia dan power within atau psychological power misalnya kesadaran diri, harga diri, identitas dan ketegasan (know how tobe), kemampuan mengatur emosi, dan lain-lain.

\section{Saran}

Untuk pihak Gapoktan Subur Mukti, kepengurusan Gapoktan akan lebih baik memiliki kepengurusan tersendiri dari Poktan Subur Mukti sehingga tidak terjadi kepengurusan ganda; untuk meningkatkan rasa solidaritas antarpoktan binaan, sebaiknya ada pertemuan rutin antarpoktan; selanjutnya untuk perwakilan pelatihan yang diselenggarakan pemerintah akan lebih baik jika ketua didampingi oleh salah satu pengurus poktan secara bergantian, sehingga masing-masing pengurus poktan memiliki pengalaman langsung dalam mengikuti pelatihan dan kemitraan dengan Gapoktan lain.

Bagi penyuluh pendamping pertanian, dalam pembelajaran akan lebih baik jika moderator diserahkan kepada anggota Gapoktan secara bergantian terutama wanita, sehingga keberanian mengungkapkan pendapat terlatih. Untuk menciptakan anggota Gapoktan yang swadaya, maka penyuluh akan lebih baik menggali peluangpeluang yang ada di lingkungan masyarakat itu sendiri, sehingga anggota Gapoktan tidak tergantung 
pada lingkungan luar khususnya pemerintah.

Rekomendasi untuk penelitian selanjutnya meneliti mengenai pengaruh usia, power within atau psycological power terhadap keberdayaan.

\section{DAFTAR PUSTAKA}

Chanan, G. (2009). Evaluating empowerment reconciling indicators with local experience. National empowerment partnership shoutwest foundation. [Online]. Tersedia: http://siteresources. worldbank.org/INTEMPOWERMENT/ Resources/486312-1095094954594/draft2. pdf. [28 Juli 2010].

Commision on Woman and Development. (2007). The women empowerment approach. [Online]. Tersedia: http://www.atol.be/docs/publ/ gender/women_empowerment_approach_ CVO.pdf [28 Juli 2010].

Friedmann,J. (1992). Empowerment: The politics of alternative development. Cambridge: Balckwell.

Hikmat, H. (2004). Strategi pemberdayaan masyarakat. Bandung: Humaniora Utama Press.

Ife, J.(1995). Community development: Creating community alternatives vision analysis \& practise (third ed.). Sydney: Addison Wesley Longman Australia Pty Ltd.

Ife, J.,\& Tesoriero F. (2006). Community development: community based alternatives in an age of globalisation. Franches Forest NSW 2086: Pearson Education Australia Pty Ltd.

Kamil,M. (2009). Pendidikan nonformal: pengembangan melalui pusat kegiatan belajar masyarakat (pkbm) di Indonesia (sebuah pembelajaran dari kominkan Jepang). Bandung: Alfabeta.

Kindervatter, S. (1979). Nonformal education as an empowering process. Massachusetts: Center for Internasional Education University of Massachusetts.
Laverack, G. (2001). An Identification and Interpretation of The Organizational Aspect of Community Empowerment. Oxford University Press and Community Development Journal. [Online]. Tersedia: http://www.bridge.ids. ac.uk/reports/re40c.pdf. [26 Agustus 2010].

Mehchy, Z.,\& Kabbani, N. (2007). Conceptualising community empowerment. [Online]. Tersedia: http://www.syriatrust.org/site/images/files/ CommunityEmpowerment070606.pdf [26 Agustus 2010].

Prayitno, B. (2009). Mengenal metode social group work dalam praktik pekerjaan sosial.[Online]. Tersedia: http://rumbai.depsos.go.id/modules. php $?$ name $=$ News $\&$ file $=$ article $\&$ sid $=9[5$ Oktober 2010].

Setiawan, I. (2008). “Menyoal Pemberdayaan”. Pikiran Rakyat. [19 September 2008].

Smith, M. K. (2004). Gertrude Wilson And Social Group Work. The Encyclopedia of Informal Education. http://www.infed.org/thinkers/ wilson.htm. [11 Oktober 2010].

Sudjana, D. (2004). Pendidikan nonformal. Bandung: Falah Production.

Suharto, E. (2006). Membangun masyarakat memberdayakan rakyat. Bandung: Refika Aditama.

Syahyuti. (2010). Kebijakan pengembangan gabungan kelompok tani (gapoktan) sebagai kelembagaan ekonomi di perdesaan. [Online]. Tersedia: http://icnie.org/2010/05/kebijakanpengembangan-gabungan-kelompok-tanigapoktan-sebagai-kelembagaan-ekonomi-diperdesaan/ [19 Juli 2010].

Trecker, H. (1948). Social group work: Principles and practices. New York: Woman's Press. 